\title{
IDENTIFIKASI DAN PREVALENSI CACING PADA SALURAN PENCERNAAN IKAN KEMBUNG (Rastrelliger brachysoma) DI PELABUHAN PERIKANAN NUSANTARA BRONDONG, LAMONGAN, JAWA TIMUR
}

\author{
Identification and Prevalence of Gastrointestinal Worms in Mackerel (Rastrelliger \\ Brachysoma) in the Nusantara Fisheries Port Brondong, Lamongan, East Java
}

\author{
Muhammad Herman ${ }^{1}$,Gunanti Mahasri ${ }^{2}$ dan Sri Subekti ${ }^{2}$ \\ ${ }^{1}$ Program Studi Budidaya Perairan, Fakultas Perikanan dan Kelautan, Universitas Airlangga, Surabaya \\ ${ }^{2}$ Departemen Manajemen Kesehatan Ikan dan Budidaya Perairan, Fakultas Perikanan dan Kelautan, Universitas \\ Airlangga, Surabaya \\ *m-herman-10@fpk.unair.ac.id
}

\begin{abstract}
Abstrak
Tingginya minat masyarakat terhadap ikan laut, mengakibatkan meningkatnya permintaan terhadap ikan kembung (Rastrelliger brachysoma). Ikan kembung merupakan salah satu komoditas yang memiliki nilai ekonomis dan nilai gizi yang cukup tinggi. Ikan kembung tersebut didapatkan dari hasil tangkap para nelayan di wilayah pesisir laut Jawa dan sekitarnya. Akan tetapi ikan ini bisa saja terserang oleh penyakit akibat infeksi dari endoparasit yang disebabkan cacing. Penyakit yang menyerang ikan kembung kemungkinan disebabkan faktor lingkungan menurun sehingga menurunkan daya tahan tubuh, menyebabkan ikan mudah terinfeksi oleh cacing endoparasit seperti halnya Anisakis. Cacing tersebut bersifat zoonosis dan dapat menginfeksi manusia, oleh karena itu dilakukan identifikasi dan prevalensi agar manusia yang mengkonsumsi dapat mengelola ikan dengan benar. Tujuan dari penelitian ini adalah untuk identifikasi dan mengetahui prevalensi cacing apa saja yang menginfeksi ikan kembung (Rastrelliger brachysoma) dari hasil tangkapan nelayan di Pelabuhan Perikanan Nusantara Brondong, Lamongan. Hasil penelitian dari identifikasi ditemukan larva Anisakis simplex stadium tiga yang menginfeksi di bagian mukosa dan bagian lumen usus ikan kembung, di wilayah Pelabuhan Perikanan Nusantara Brondong, Lamongan dengan total prevalensi cacing Anisakis simplex sebesar 9.6\%.
\end{abstract}

Kata kunci : Identifikasi, Prevalensi, Ikan Kembung (Rastrelliger brachysoma), Anisakis simplex

\section{Abstract}

The high interest of public to Marine fish, making more request of mackerel (Rastrelliger brachysoma). Mackerel is one of commodity that has economic and high nutrient value. Mackerel which were used in this research were obtained from the catch of the fishermen in the coastal areas of Java and the surrounding sea. However, these fish could be attacked by diseases caused by infection of endoparasites of worms. The disease that infected mackerel probably caused by pollution due to environmental factorsthat could decreased the immune system, and making a fish easily infected by endoparasitic worm as Anisakis. This parasite is zoonosis and could infect to human. Therefore, identification and prevalence of this parasite was neededin order to human consumed and managed this fish correctly. The purpose of this study was to identify and to know the prevalence of this wormthat infected a mackerel fish (Rastrelliger brachysoma) from fishermen catches in the Nusantara Fisheries Port Brondong, Lamongan. The result showed the presence of Anisakis simplex was third-stage larvae that infected the mucosa and lumen of intestinal of mackerel fish,in the Nusantara Fisheries Port Brondong, Lamongan with prevalence was 9.6\%.

Key word: Identification, Prevalence, Mackerel (Rastrelliger brachysoma), Anisakis simplex

\section{PENDAHULUAN}

Ikan kembung (Rastrelliger brachysoma) merupakan salah satu jenis ikan air laut yang memiliki nilai ekonomis yang cukup tinggi. Selain nilai ekonomis, nilai gizi yang dimiliki ikan ini cukup tinggi. Kandungan gizi yang sangat menonjol dari ikan kembung antara lain protein. Kalsium dan vitamin A. Data yang didapat untuk setiap $100 \mathrm{~g}$ dari daging ikan kembung didapatkan $22 \mathrm{~g}$ komposisi dari protein, $12 \mathrm{~g}$ kalsium dan adanya vitamin $\mathrm{A}$ 
yang cukup tinggi sebesar $30 \mathrm{mg}$ (Lakshmanan et al., 1991).

Berdasarkan data Direktorat Jenderal Perikanan (2010), menunjukkan bahwa produksi seluruh ikan pada tahun 2010 mencapai jumlah 69.585 ton, bisa dikatakan cukup tinggi. Sampai saat ini ikan kembung yang dijual di pasar domestik maupun internasional masih berasal dari tangkapan alam dari berbagai daerah di Indonesia. Salah satu pelabuhan yang mendapatkan hasil tangkap ikan kembung adalah Pelabuhan Perikanan Nusantara (PPN) Brondong, Lamongan. PPN Brondong merupakan salah satu pelabuhan perikanan yang berada di daerah pesisir utara pulau Jawa. Keberadaan pelabuhan perikanan ini memiliki nilai peran yang cukup strategis dalam pembangunan ekonomi Kabupaten Lamongan (Jannah, 2013).

Ikan kembung hidup di wilayah pesisir dekat pantai. Daerah penyebaran ikan kembung di Indonesia antara lain Laut Jawa, Selat Malaka, Laut Flores dan Laut Banda. Ikan kembung keluar ke permukaan air pada malam hari dan pada siang hari masuk ke dalam perairan.

Ikan kembung sebagai salah satu ikan laut yang umum dikonsumsi manusia, pada saluran pencernaannya dapat ditemukan berbagai jenis cacing parasit baik dalam bentuk larva maupun cacing dewasa. Berbagai kerugian dapat ditimbulkan akibat infeksi cacing parasit ini, antara lain kerugian ekonomi, kesehatan dan ekologi (Khairunnisa, 2007). Oleh karenanya diperlukan pemahaman dan pengendalian terhadap cacing parasitik dan penyakit yang ditimbulkannya terutama yang berasal dari ikan untuk dapat mengembangkan berbagai produk asal ikan terutama untuk konsumsi manusia (Yamaguti, 1958). Lebih lanjut parasit zoonosis pada ikan akan menjadi sebuah masalah apabila konsumen mengkonsumsi dalam keadaan mentah seperti halnya sashimi dan sushi (Neta, 2006). Parasit zoonosis adalah parasit yang bisa menyerang manusia.
Cacing parasit ini bisa ditemukan pada saluran pencernaan maupun di insang.

\section{METODOLOGI}

\section{Waktu dan Tempat}

Penelitian ini dilaksanakan di Laboratorium Kering Fakultas Perikanan dan Kelautan Universitas Airlangga Surabaya dan Pelabuhan Perikanan Nusantara Brondong, Lamongan, Jawa Timur. Penelitian telah dilaksanakan pada bulan Agustus - November 2013.

\section{Materi Penelitian}

Peralatan Penelitian

Peralatan yang digunakan untuk pengambilan sampel penelitian antara lain sekop, bak dan kantong plastik. Untuk proses identifikasi endoparasit alat yang digunakanpisau bedah (scalpel), gunting bedah, pinset, object glass, cover glass, pipet tetes, cawan Petri, tabung sentrifus, mesin sentrifus dan mikroskop.

Bahan Penelitian

Bahan penelitian yang digunakan antara lain, ikan sampel berupa ikan kembung berjumlah 125 ekor dengan ukuran 10-25 cm, alkohol gliserin 5\%, alkohol asam, alkohol basa, alkohol 70\%, larutan Carmine, alkohol 85\%, alkohol 95\% dan Entelan (Gay and Diehl, 1992).

\section{Metode Penelitian}

Penelitian ini menggunakan metode survei melalui pengambilan sampel pada lokasi secara langsung. Lokasi pengambilan sampel ikan ditentukan dengan cara sengaja (purposive sampling) sesuai dengan pernyataan Silalahi (2003). Metode pengambilan sampel dilakukan secara acak (random sampling) terhadap ikan kembung di Pelabuhan Nusantara Brondong, Jawa Timur.

\section{Prosedur Kerja \\ Persiapan Alat dan Bahan}

Persiapan yang dilakukan adalah melakukan sterilisasi gunting, pinset, pisau bedah dan nampan sebelum digunakan, 
yaitu mencuci hingga bersih alat tersebut menggunakan sabun kemudian dikeringkan, setelah itu direndam di dalam alkohol $70 \%$. Selanjutnya mempersiapkan ikan sampel yang akan diamati dengan mengambil secara acak.

\section{Pengambilan Sampel}

Sampel ikan kembung yang diteliti diambil dari Pelabuhan Nusantara Brondong Lamongan Jawa Timur. Ikan hasil tangkapan nelayan yang berasal di daerah di sekitar laut Jawa. Sampel ikan yang diambil dalam keadaan segar sebanyak 125 ekor dari tangkapan nelayan. Yang dilakukan lima kali pengambilan, setiap pengambilan sampel sebanyak 25 ekor ikan Kembung. Sampel yang digunakan adalah ikan kembung yang memiliki ukuran panjang 10-25 cm. Pengambilan sampel ikan yang diambil sebesar $5-10 \%$ dari jumlah total populasi ikan, dari jumlah populasi rata-rata tangkapan ikan kembung di Pelabuhan Perikanan Nusantara Brondong sebanyak 500 ekor setiap hari. Pengambilan sampel ikan dilakukan sebanyak lima kali.

\section{Pemeriksaan dan Identifikasi Cacing pada Saluran Pencernaan Ikan Kembung}

Sampel diambil kemudian diletakkan di atas nampan, kemudian ikan ditimbang dan diukur panjangnya. Dilakukan pembedahan dengan gunting mengarah ke anterior tubuh sampai pada bagian sirip ventral, kemudian digunting ke arah dorsal ikan sampai pada bagian gurat sisi lalu digunting mengarah pada bagian anal ikan. Lambung ikan bagian anterior dipotong sampai pada bagian posterior usus, kemudian disimpan di dalam alkohol gliserin 5\% untuk dilakukan pemeriksaan parasit. Pemeriksaan parasit saluran pencernaan ikan kembung dilakukan dengan mengeluarkan feses dengan mengurut mengarah ke ujung posterior usus. Feses yang telah keluar kemudian di letakkan di atas object glass dan ditetesi air kemudian diamati di bawah mikroskop dengan pembesaran 100x. Identifikasi parasit dilakukan berdasarkan Grabda (1991) dan Kabata (1985).

\section{Pewarnaan Cacing pada Saluran Pencernaan Ikan Kembung}

Pewarnaan cacing menggunakan metode Semichen-Acetic Carmine yang mengacu pada Kuhlman (2006) dengan cara cacing disimpan dalam alkohol gliserin 5\% lalu di fiksir di antara dua object glass dan ikat kedua ujungnya dengan benang. Kemudian dimasukkan dalam alkohol $70 \%$ selama lima menit. Setelah itu, memindahkan cacing dalam larutan carmine yang sudah diencerkan dengan alkohol $70 \%$ dengan perbandingan 1 : 2, dibiarkan selama empat jam, kemudian cacing dilepas dari obyect glass, lalu dipindahkan dalam larutan alkohol asam selama dua menit (alkohol 70\% + $\mathrm{HCl}$ ). Setelah selesai, dipindahkan dalam larutan alkohol basa selama 20 menit (alkohol 70\% + NaHCO3). Selanjutnya dilakukan dehidrasi bertingkat dengan alkohol 70\% selama lima menit, alkohol $85 \%$ selama lima menit dan alkohol 95\% selama lima menit. Kemudian dilakukan mounting dengan menggunakan larutan entelan, cacing diambil lalu di letakkan di object glass, dan ditetesi entelan, kemudian menutup dengan cover glass.

\section{Parameter Penelitian}

Pada penelitian ini parameter utama yang diamati adalah jenis cacing endoparasit pada saluran pencernaan ikan kembung (Rastrelliger brachysoma) dan prevalensinya. Prevalensi adalah besarnya jumlah prosentase ikan yang terinfeksi dari ikan yang diperiksa (Karantina Ikan Kelas I Hang Nadim, 2010).

\section{HASIL DAN PEMBAHASAN Hasil}

Penelitian dilakukan dengan pengamatan secara mikroskopis, yaitu dengan melakukan pembedahan pada saluran pencernaan ikan setelah itu dilakukan insisi pada organ yang sudah

Diterima/submitted:21 November 2013

Disetujui/accepted:11 Desember 2013 
diambil, kemudian dilakukan pengamatan menggunakan mikroskop dengan pembesaran 40x dan 100x. Hasil penelitian yang dilakukan terhadap 125 sampel ikan Kembung (Rastrelliger brachysoma) yang diambil sebanyak lima kali pengambilan, setiap pengambilan sampel sebanyak 25 ekor. Hasil identifikasi endoparasit pada saluran pencernaan ikan kembung hanya ditemukan larva stadium tiga dari Anisakis simplex (Grabda, 1991).

Larva Anisakissimplex yang ditemukan memiliki bentuk tubuh silindris memanjang dan cenderung mengalami pelebaran pada bagian posteriornya. Larva Anisakis simplex memiliki mukron pada bagian posteriornya. Larva Anisakis simplex yang ditemukan memiliki warna putih susu, berukuran panjang $15-27 \mathrm{~mm}$ dan diameter 0.4-0.9 mm. Larva Anisakis simplex yang ditemukan memiliki saluran ekskresi pada bagian posterior (Gambar 2), selain itu juga ditemukan oesophagus yang lurus, berbentuk silindris atau sedikit mengalami pelebaran di bagian posteriornya, terdiri atas dua bagian, yaitu bagian anterior yang berupa otot dan bagian posterior yang berbentuk kelenjar, dikenal sebagai ventrikulus (Gambar 1). Selain itu juga ditemukan anus pada bagian ventral posterior dari larva Anisakis simplex. Hasil penelitian menunjukkan bahwa ditemukan Larva stadium tiga dari jenis Anisakis simplex dan tidak ditemukannya telur cacing pada ikan kembung dari hasil tangkapan nelayan yang didaratkan di Pelabuhan Perikanan Nusantara Brondong, Lamongan.

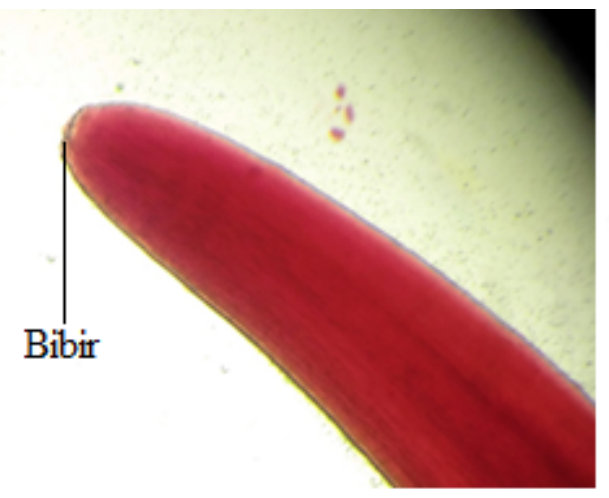

(A)

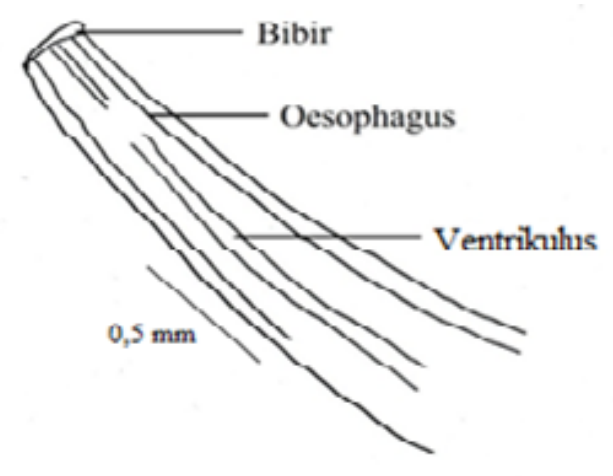

(B)

Gambar 1. Bagian anterior larva Anisakis simplex stadium tiga (perbesaran 100x).

A. Foto bagian anterior larva Anisakis simplex dengan mikroskop Binokuler.

B. Gambar bagian anterior larva Anisakis simplex dengan kameraLucida pada mikroskop Binokuler. 


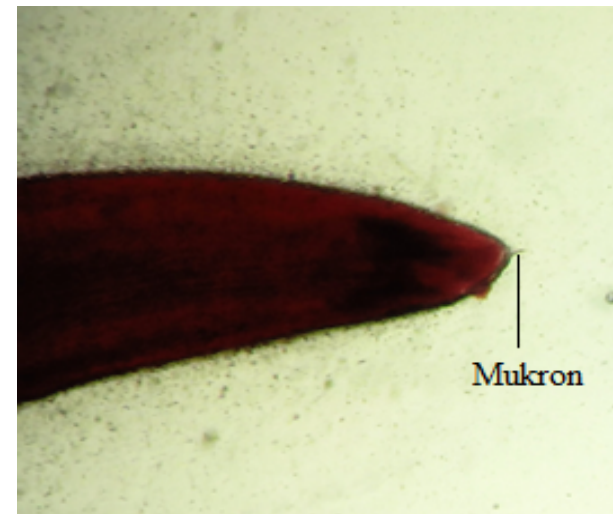

(A)

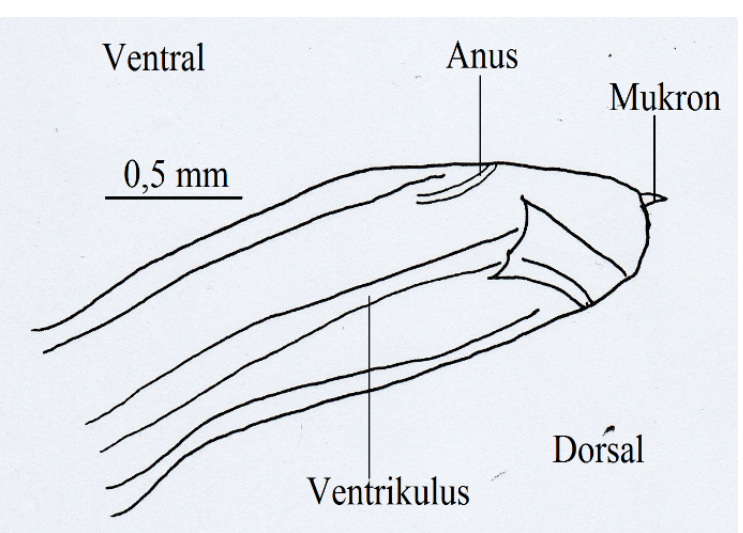

(B)

Gambar 2. Bagian posterior tubuh larva Anisakis simplex stadium tiga (pembesaran 100x).

A. Foto bagian posterior larva Anisakis simplex dengan mikroskop Binokuler.

B. Gambar bagian posterior larva Anisakis simplex dengan kamera Lucida pada mikroskop Binokuler.

\section{Prevalensi Larva Anisakis simplex pada Saluran Pencernaan Ikan Kembung}

pengambilan sampel bervariasi. Data hasil perhitungan prevalensi endoparasit ikan kembung dapat dilihat pada Tabel 1.

Tabel 1. Hasil Perhitungan Prevalensi Larva Stadium Tiga Anisakis simplex Pada Saluran Pencernaan Ikan Kembung

\begin{tabular}{cccc}
\hline Pengambilan Ke - & $\begin{array}{c}\text { Jumlah sampel yang } \\
\text { diperiksa(ekor) }\end{array}$ & $\begin{array}{c}\text { Jumlah ikan yang } \\
\text { terinfeksi (ekor) }\end{array}$ & Prevalensi (\%) \\
\hline 1 & 25 & 5 & 20 \\
2 & 25 & 3 & 8 \\
3 & 25 & 2 & 12 \\
4 & 25 & 1 & 4 \\
5 & 25 & 12 & 4 \\
Total & 125 & & 48 \\
Rata-rata & & & 9,6 \\
\hline
\end{tabular}

Hasil perhitungan prevalensi terhadap 25 sampel ikan dari setiap kali pengambilan sampel di Pelabuhan Perikanan Nusantara Brondong, Lamongan diperoleh data dari setiap pengambilan adalah, pada pengambilan pertama ikan kembung yang terinfeksi Anisakis simplex sebesar 20\%, kedua sebesar $8 \%$, ketiga sebesar $12 \%$, keempat dan kelima prevalensi Anisakis simplex yang ditemukan sebesar 4\%. Anisakis simplex tersebut ditemukan pada bagian mukosa dan lumen usus ikan Kembung. Larva Anisakis simplex yang ditemukan memiliki bentuk seperti "Coil" dan lurus. Prevalensi rata-rata ikan kembung yang terinfeksi Anisakis simplex hasil tangkapan di PPN Brondong, Lamongan sebesar 9.6\% (12 sampel terinfeksi dari total 125 sampel).

\section{Pembahasan}

Cacing endoparasit yang ditemukan pada penelitian ini termasuk dalam Phylum Nemathelmintes, Kelas Nematoda, Ordo Ascaridida, Famili Anisakidae, Genus Anisakis dan Species Anisakis simplex (Grabda, 1991).

Hasil penelitian menunjukkan bahwa ditemukan larva stadium tiga Anisakis simplex di mukosa dan lumen 
usus ikan kembung, hasil tangkap dari Pelabuhan Perikanan Nusantara Brondong, Lamongan. Larva stadium tiga yang berasal dari kelas Nematoda ini umumnya berada di saluran pencernaan ikan yang terinfeksi, di bagian mukosa usus dan bagian lumen usus besar. Hal ini disebabkan ikan terinfeksi karena memakan crustacea yang di dalam tubuhnya mengandung larva stadium dua dari Anisakis simplex.

Crustacea berperan sebagai inang perantara pertama, hal ini sesuai dengan pernyataan Nuchjangreed et al.,(2006). Hasil perhitungan menunjukkan bahwa prevalensi larva stadium tiga Anisakis simplex pada setiap pengambilan sampel bervariasi dan prevalensi terendah terjadi pada pengambilan sampel ke empat dan lima menunjukkan prevalensi sebesar $4 \%$. Rendahnya prevalensi larva Anisakis simplex pada pengambilan sampel ke empat dan lima dipengaruhi oleh ukuran panjang dari tubuh ikan yang relatif lebih kecil dibanding pengambilan sampel ke satu, dua dan tiga.

Prevalensi larva stadium tiga Anisakis simplex yang menyerang ikan rata-rata sebesar 9.6\%. Hal ini kemungkinan disebabkan karena ikan kembung (Rastrelliger brachysoma) termasuk dalam jenis ikan Oceanodromus yang melakukan perpindahan dari wilayah pantai menuju daerah laut lepas yang bertujuan untuk melakukan pemijahan. Hal ini menyebabkan daya tahan tubuh ikan tersebut menurun sehingga lebih mudah terinfeksi oleh parasit.

Menurut Rucket et al. (2009), keberadaan cacing endoparasit di dalam tubuh ikan juga bisa disebabkan karena adanya organisme invertebrata seperti crustacea di sekitar habitat dari ikan kembung, yang juga merupakan salah satu jenis pakan alami dari ikan kembung. Tidak ditemukannya cacing lain seperti Lecithocladium scombri pada saluran pencernaan ikan kembung kemungkinan dikarenakan tidak terdapat mollusca di sekitar habitat ikan kembung yang ditangkap, mollusca merupakan salah satu jenis pakan alami dari ikan kembung. Mollusca merupakan inang antara pertama dari cacing Lecithocladium scombri, Lecithocladium scombri menginfeksi molluscapada saat fase miracidium. Pada saat fase Miracidium cacing Lecithocladium scombri berkembang menjadi cercaria di dalam tubuh molluca.

Selain faktor-faktor di atas, ditemukannya endoparasitpada saluran pencernaan ikan kembung (Rastrelliger brachysoma) di perairan laut dan diambil di Pelabuhan Perikanan Nusantara Brondong, Lamongan, kemungkinan juga karena adanya limbah industri, yang menyebabkan menurunnya kualitas air di sekitar daerah pengambilan sampel, sehingga menurunnya kualitas air dapat menyebabkan daya tahan tubuh dari ikan menurun dan ikan tersebut mudah terinfeksi oleh parasit (Yuliarti, 2011).

\section{KESIMPULAN DAN SARAN Kesimpulan}

Berdasarkan hasil identifikasi cacing pada saluran pencernaan ikan kembung (Rastrelliger brachysoma) yang di ambil di Pelabuhan Perikanan Nusantara Brondong, Lamongan, di temukan larva cacing Anisakis simplex stadium tiga. Prevalensi larva Anisakis simplex yang ditemukan sebesar $9.6 \%$.

\section{Saran}

Dengan ditemukannya cacing Anisakis simplex pada saluran pencernaan ikan kembung (Rastrelliger brachysoma), maka diperlukan pengolahan yang baik dan benar sebelum ikan tersebut dikonsumsi manusia, karena bersifat zoonosis.

\section{DAFTAR PUSTAKA}

Direktorat Jenderal Perikanan. 2010. Statistik Perikanan Indonesia 2008. Departemen Pertanian. Jakarta. 75 hal.

Gay, L.R. and P. L. Diehl. (1992), Research Methods for Business

Diterima/submitted:21 November 2013 Disetujui/accepted: 11 Desember 2013 
and Management, MacMillan Publishing Company, New York.

Grabda J. 1991. Marine Fish Parasitology. Poland: Polish Scientific Publishers, Warsawa.

Jannah, Roudlatul. 2013. Konflik Sosial Di Tempat Pelelangan Ikan Di Brondong Tahun 1998. Avatara, ejournal Pendidikan Sejarah.

Kabata, Z. 1985. Parasites and Diseases of Fish Cultured in the Tropics. Taylor and Francis. London and Philadelphia.

Khairunnisa. 2007. Minyak cengkeh (Eugenia aromatica) dan Kalium Hidroksida $10 \%$ Sebagai Bahan Pewarna Semi Permanen Pada Cacing Nematoda dan Acanthocephala Ikan Air Laut. [Skripsi]. Bogor: Fakultas Kedokteran Hewan, Institut Pertanian Bogor.

Kuhlmann, W.F. 2006. Preservation, Staining, and Mounting Parasite Speciment. 8hal.

Lakshmanan R, V RAO Venugopal and DRBYK Bongirwar. 1999. Stability of lipids of Indian mackerel to gamma irradiation. The Journal of Food Lipids 6(4) 277-285.

Neta MYR. 2006. Identifikasi Cacing Acanthocephala pada Saluran Pencernaan Ikan Tuna (Famili Scrombidae). [Skripsi]. Bogor: Fakultas Kedokteran Hewan, Institut Pertanian Bogor.

Nontji A. 2007. Laut nusantara. Djambatan. Jakarta.

Nuchjangreed C., Z. Hamzah, P. Suntornthiticharoen and P.S. Muntawarasilp. 2006. Anisakid in Marine Fish from the Coast of Chon Buri Province, Thailand.

Rucket, S., S. Klimpel, S. Al-Quraishy, H. Mehlhron, and H.W. Palm. 2009. Transmission of Fish Parasites into Grouper Mariculture (Serranidae: Epinephelus coioides (Hamilton,
1882)) in Lampung Bay, Indonesia. Parasitol 104: 523-532.

Yamaguti S. 2007. Parasitic Worm Mainly from Celebes. Acta Medica Okayama.

Yuliartati, E. 2011. Tingkat Serangan Ektoparasit pada Ikan Patin (Pangasius djambla) pada Beberapa Pembudidaya Ikan di Kota Makassar. Skripsi. Program Studi Budidaya Perairan. Jurusan Perikanan. Fakultas Ilmu Kelautan dan Perikanan. Universitas Hasanuddin. Makassar. 65 hal. 